\title{
Synthesis and Pharmacological Evaluation of $\mathrm{DH} \beta \mathrm{E}$ Analogues as Neuronal Nicotinic Acetylcholine Receptor Antagonists
}

\author{
Tue Heesgaard Jepsen, Anders A. Jensen, Mads Henrik Lund, Emil Glibstrup,
} and Jesper Langgaard Kristensen*

Department of Drug Design and Pharmacology, Faculty of Health and Medical Sciences, University of Copenhagen, Universitetsparken 2, 2100 Copenhagen, Denmark

Supporting Information

ABSTRACT: Dihydro- $\beta$-erythroidine $(\mathrm{DH} \beta \mathrm{E})$ is a member of the Erythrina family of alkaloids and a potent competitive antagonist of the $\alpha 4 \beta 2$-subtype of the nicotinic acetylcholine receptors (nAChRs). Guided by an X-ray structure of $\mathrm{DH} \beta \mathrm{E}$ in complex with an ACh binding protein, we detail the design, synthesis, and pharmacological characterization of a series of $\mathrm{DH} \beta \mathrm{E}$ analogues in which two of the four rings in the natural product has been excluded. We found that the

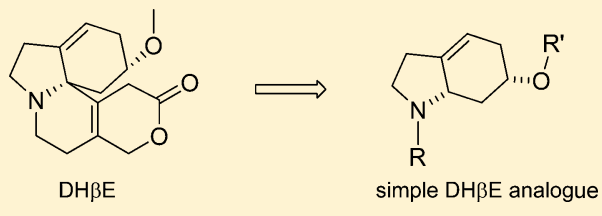
direct analogue of $\mathrm{DH} \beta \mathrm{E}$ maintains affinity for the $\alpha 4 \beta 2$-subtype, but further modifications of the simplified analogues were detrimental to their activities on the nAChRs.

KEYWORDS: Dihydro- $\beta$-erythroidine, $n A C h R$, antagonist, natural product analogues

$\mathrm{T}$ he neuronal nicotinic acetylcholine receptors ( $\mathrm{AAChRs)}$ have been extensively explored as putative drug targets for a diverse array of medical conditions in relation to the central nervous system (CNS). Generally speaking, the vast majority of the existing ligands for the neuronal nAChRs to date are agonists, partial agonists, or modulators, and in contrast, much less research has been directed toward antagonists. ${ }^{1-5}$ This is somewhat surprising since competitive as well as noncompetitive antagonists of the nAChRs has been indicated as targets for several therapeutic applications including autism (for which there is currently no efficient treatment), pain, depression, and drug and tobacco dependency. ${ }^{6-11}$ The serotonin and/or the norepinephrine systems are the primary targets for the existing antidepressants, but recently the possibility of treating depression with $\mathrm{nAChR}$ antagonists has been explored. $^{7-12}$ An in vivo study in mice (forced swim and mouse suspension) have demonstrated antidepressive effects for antagonists (like dihydro- $\beta$-erythroidine $(\mathrm{DH} \beta \mathrm{E})$, mecamylamine, and MLA) and no effects for agonists (like nicotine), which further strengthens the argument for the development of antidepressant therapeutics from $\mathrm{nAChR}$ antagonists. ${ }^{13}$ Most of the available selective $\mathrm{nAChR}$ antagonists are natural products with a pronounced complexity and size that makes them unsuitable as lead compounds for drug discovery. $\mathrm{DH} \beta \mathrm{E}$ is a member of the Erythrina alkaloids, which were isolated from Erythrina species in the end of the 19th century, and the majority of this family possess neuromuscular blocking effect. $\mathrm{DH} \beta \mathrm{E}$ is one of the most potent $\mathrm{nAChR}$ antagonists of this class and displays selectivity for the $\alpha 4 \beta 2$ subtype (with a binding affinity of $0.82 \mu \mathrm{M}$ at the receptor in a $\left[{ }^{3} \mathrm{H}\right]$ epibatidine binding assay), and the compound has been employed as a pharmacological tool in a variety of in vitro and in vivo studies. $^{14,15}$
$\mathrm{DH} \beta \mathrm{E}$ has found applications in humans as well, as an orally administered muscle relaxant in the treatment of Parkinson's disease, for treatment of spastic disorders, and in the treatment of muscular spasms related to tetanus. ${ }^{16,17}$ In general, $\mathrm{DH} \beta \mathrm{E}$ has potential efficacy for the treatment of depression, ${ }^{18}$ and even though $\mathrm{DH} \beta \mathrm{E}$ is a reference antagonist for the $\alpha 4 \beta 2$ nAChR, no comprehensive structure-activity relationship (SAR) of $\mathrm{DH} \beta \mathrm{E}$ has been reported so far. With its unique tetracyclic spiroamine scaffold, $\mathrm{DH} \beta \mathrm{E}$ seemed to be a suitable template to create a SAR of simpler derivatives in order to develop small subtype selective $\mathrm{nAChR}$ antagonists. A recently published X-ray structure of the acetylcholine binding protein $(\mathrm{AChBP})$ in complex with $\mathrm{DH} \beta \mathrm{E}^{19}$ has revealed two key pharmacophoric elements of $\mathrm{DH} \beta \mathrm{E}$ (Chart 1a): The methoxy group in the A ring, which interacts via hydrogen bonding with a tightly bound water molecule in the protein, and the protonated amine, which hydrogen bonds directly with the backbone of the protein. These results indicate that the key pharmacophoric elements are located in the A ring and the $\mathrm{B} / \mathrm{C}$ ring, whereas it was previously suggested that the binding interactions were found in the $\mathrm{C}$ and $\mathrm{D}$ rings. ${ }^{20}$ We recently published a SAR on the $\mathrm{CD}$ ring system of the aromatic erythrinanes, and while reducing the complexity, we were able to retain affinity, subtype specificity, and function for competitive antagonists in the analogues. ${ }^{21}$ Moreover, the lead compound from this series of analogues was shown to possess antidepressant-like effect in vivo. ${ }^{21}$

In view of these promising results, we set out to investigate the $\mathrm{AB}$ ring system in greater detail. Our strategy was to "deconstruct" the $\mathrm{DH} \beta \mathrm{E}$ framework by excluding rings $\mathrm{C}$ and

Received: March 4, 2014

Accepted: May 20, 2014

Published: May 20, 2014 
Chart 1. DH $\beta$ E and Related Structures ${ }^{a}$

a)

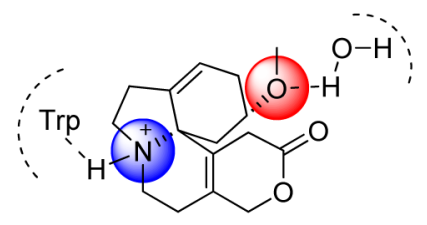

Tetracyclic erythrina framework Key $\mathrm{DH} \beta \mathrm{E}$ pharmacophores

b)

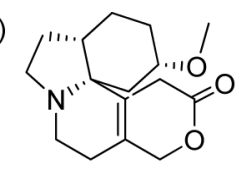
THBE

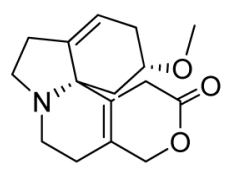

$\mathrm{DH} \beta \mathrm{E}$

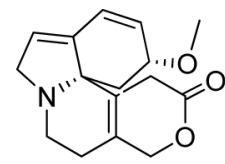

$\beta E$

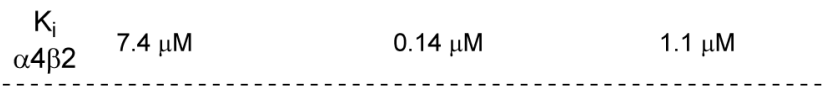

c)

Ligands targeted in this study:<smiles>[R]O[C@@H]1CC[C@@H]2CCN([R])[C@H]2C1</smiles>

$\mathrm{TH} \beta \mathrm{E}-$-analogue (1)

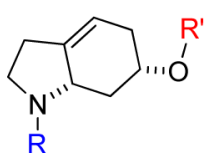

DHßE-analogue (2)

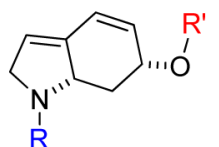

$\beta E$-analogue (3)
${ }^{a}$ The $K_{\mathrm{i}}$ values for $\alpha 4 \beta 2$ are obtained from a rat membrane $\left[{ }^{3} \mathrm{H}\right]$ cytisine binding assay. ${ }^{22}$

$\mathrm{D}$ and thus retain the key pharmacophores of the $\mathrm{A}$ and $\mathrm{B}$ rings, as indicated in the $\mathrm{X}$-ray structure. Previous studies featuring direct comparison of the parent natural products (Chart $1 \mathrm{~b}$ ) with none, one, and two double bonds (i.e., $\beta$-erythroidine $(\beta \mathrm{E})$, dihydro- $\beta$-erythroidine $(\mathrm{DH} \beta \mathrm{E})$, and tetrahydro- $\beta$ erythroidine $(\mathrm{TH} \beta \mathrm{E}))$ indicate that the saturation state of the carbon framework has a significant impact on the nAChR affinities of the compounds. ${ }^{22}$ Erythrinanes with a fully saturated $\mathrm{AB}$ ring system (as in $\mathrm{TH} \beta \mathrm{E}$, which is available via hydrogenation of $\mathrm{DH} \beta \mathrm{E}$ ) are yet to be isolated from natural sources, whereas the di-unsaturated $\mathrm{AB}$-ring system (as in $\beta \mathrm{E}$ ) is also present in a number of aromatic Erythrina alkaloids; several of which display high binding affinity for the $\alpha 4 \beta 2$ nAChR. ${ }^{20,23}$ Thus, we set out to prepare simplified $A B$ scaffolds (compounds 1, 2, and 3) mimicking the different levels of saturation (Chart 1c). Furthermore, the crystal structure of $\mathrm{AChBP}$ in complex with $\mathrm{DH} \beta \mathrm{E}$ indicated that there was sufficient space for larger substituents on the oxygen atom, so we decided to include a small series of $\mathrm{O}$-alkylated analogues as well as the free alcohol. The methoxyethyl substituent was chosen to possibly dislodge the tightly bound water molecule in the receptor and thereby create a direct interaction to the backbone of the protein. The effect of $\mathrm{N}-\mathrm{H}$ versus $\mathrm{N}-\mathrm{Me}$ substitution on the $\mathrm{AB}$ ring was also included. All compounds were targeted as racemic mixtures of pure diastereomers. Since the bicyclic derivatives all featured a 1,3-relationship between the nitrogen and the oxygen atoms in the A ring, we took advantage of the Aza-Michael addition when forming the [6,5] bicycle. In order to vary the saturation in the bicyclic cores (saturated and mono- and di-unsaturated), we needed to selectively adjust the oxidation level.

Starting from the same phenethyl amine core, either reductive or oxidative dearomatization (Birch reduction or hypervalent iodide oxidation) would give access to Michael acceptors with different oxidation levels, which after ring closure to the desired $[6,5]$ bicycle could give rise to the different saturation levels. This general plan for the fully saturated analogues (1) was reduced to practice (Scheme 1)

Scheme 1. Synthesis of Saturated AB Fragments ${ }^{a}$<smiles>NCCc1ccc(O[O-])cc1</smiles>

4<smiles>O=C(O)N1CC[C@@H]2CC[C@@H](O)C[C@H]21</smiles><smiles>[R]O[C@H]1CC[C@@H]2CCN(C(=O)OCc3ccccc3)[C@H]2C1</smiles>

7a: $\mathrm{R}=\mathrm{CH}_{3}(91 \%)$

7b: $\mathrm{R}=\mathrm{CH}_{2} \mathrm{CH}_{3}(61 \%)$

7c: $\mathrm{R}=\mathrm{CH}_{2} \mathrm{Ph}(92 \%)$

$7 \mathrm{~d}: \mathrm{R}=\mathrm{CH}_{2} \mathrm{CH}_{2} \mathrm{OCH}_{3}(41 \%)$

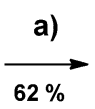

e) or f)

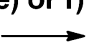

8: $\mathrm{R}=\mathrm{CH}_{3}(91 \%)$

9: $\mathrm{R}=\mathrm{H}(\mathbf{8 4} \%)$

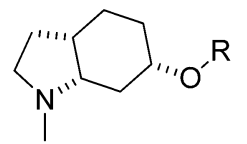

1a: $\mathrm{R}=\mathrm{CH}_{3}(92 \%)$

1b: $\mathrm{R}=\mathrm{CH}_{2} \mathrm{CH}_{3}(96 \%)$

1c: $\mathrm{R}=\mathrm{CH}_{2} \mathrm{Ph}(98 \%)$

1d: $\mathrm{R}=\mathrm{CH}_{2} \mathrm{CH}_{2} \mathrm{OCH}_{3}(89 \%)$

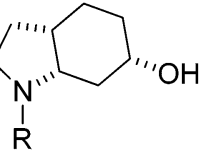

${ }^{a}$ All compounds were prepared as racemic mixtures of pure diastereomers. (a) $\mathrm{Li}, \mathrm{NH}_{3}(l), \mathrm{EtOH},-40{ }^{\circ} \mathrm{C}, 1 \mathrm{~h} ; \mathrm{HCl}(5 \mathrm{M}), 80$ ${ }^{\circ} \mathrm{C}, 3 \mathrm{~h}$; $\mathrm{Boc}_{2} \mathrm{O}$ (1 equiv), rt, 15 h, 62\% (3 steps). (b) $\mathrm{NaBH}_{4}$ (3 equiv), $\mathrm{CeCl}_{3}$ (0.15 equiv), $\mathrm{MeOH},-30{ }^{\circ} \mathrm{C}, 2 \mathrm{~h}, 89 \%$. (c) $\mathrm{NaH}(2.5$ equiv), DMF, $0{ }^{\circ} \mathrm{C}, 30 \mathrm{~min}$, then alkyl halide (3-4 equiv), rt, $12-15 \mathrm{~h}$, 7a $91 \%, 7$ b $61 \%, 7$ c $92 \%, 7 d$ d1\%. (d) LAH (3 equiv), THF, $70{ }^{\circ} \mathrm{C}, 3$ h, 1a $92 \%$, 1b 96\%, 1c 98\%, 1d 89\%. (e) LAH (3 equiv), THF, $70{ }^{\circ} \mathrm{C}$, 3 h, 8 91\%. (f) $\mathrm{HCl}$ (10 equiv), diethyl ether, rt, 2 h, $84 \%$.

commencing from 4-metoxyphenethylamine (4) via Birch reduction, ${ }^{24}$ hydrolysis to the unsaturated ketone, and subsequent Michael addition in order to complete the carbon framework of the $[6,5]$ bicycle in $62 \%$ yield. Ketone 5 was reduced diastereoselectively ${ }^{25}$ with $\mathrm{NaBH}_{4} / \mathrm{CeCl}_{3}$ to the cisamino alcohol (6) in $89 \%$ yield and subsequently O-alkylated with a selection of alkyl halides to furnish compounds $7 \mathbf{a}-\mathbf{d}$ in up to $92 \%$ yield. Finally, the Boc-protected compounds (6 and 7) were reduced with lithium aluminum hydride (LAH) to provide the tertiary methylamines $(\mathbf{1 a}-\mathbf{d}$ and $\mathbf{8})$ in excellent yields. Boc-deprotection of 6 afforded secondary amine 9 . In the case of the unsaturated analogues (2), the synthesis (Scheme 2) commenced with a phenyiodide-ditrifluoroacetate (PIFA) oxidation ${ }^{26-28}$ of $N$-Boc-tyramine $(10)$ in order to stage the di-unsaturated ketone 11 in $65 \%$ yield. Aza-Michael addition afforded the bicycle 12 in $94 \%$ yield followed by zincmediated reduction/rearrangement ${ }^{29}$ and diastereoselective reduction of the ketone to the desired homoallyllic alcohol (13) in $82 \%$ yield ( 2 steps). Standard transformations afforded the mono-unsaturated tertiary amines $(\mathbf{2 a}-\mathbf{d}$ and $\mathbf{1 6})$ as well as secondary amines (15 and 17).

The framework for the di-unsaturated analogue (3) was assembled by a similar oxidative dearomatization strategy to afford the bicyclic 19 in satisfying yields (Scheme 3 ). Dehydration of 17 with $\mathrm{POCl}_{3}{ }^{30}$ furnished dienone 20 in $86 \%$ yield followed by standard transformations to afford the desired diene (3) in 69\% yield (3 steps). 
Scheme 2. Synthesis of Mono-Unsaturated AB Fragments ${ }^{a}$
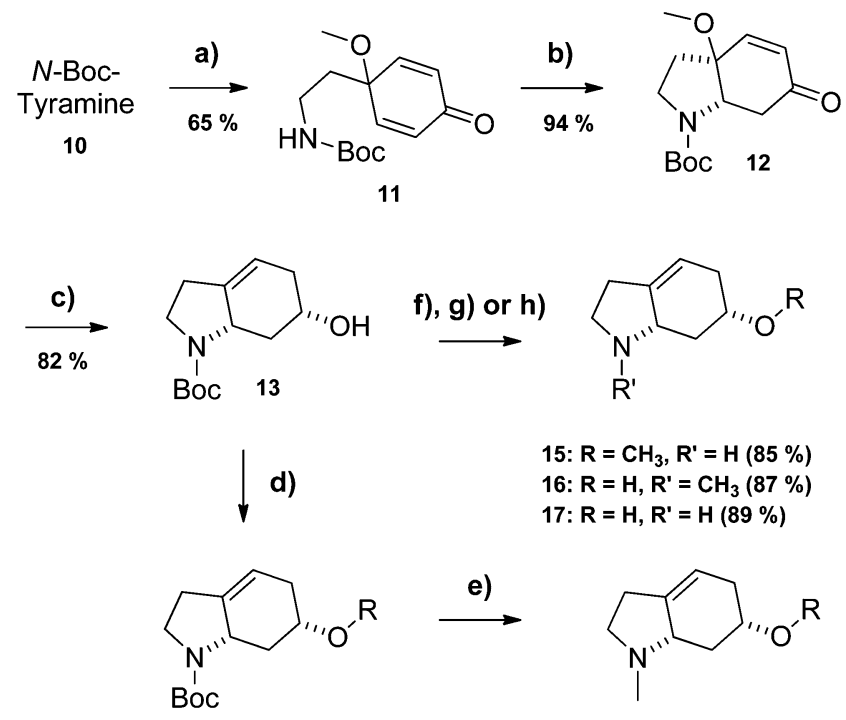

14a: $\mathrm{R}=\mathrm{CH}_{3}(89 \%)$

14b: $\mathrm{R}=\mathrm{CH}_{2} \mathrm{CH}_{3}(41 \%)$

14c: $\mathrm{R}=\mathrm{CH}_{2} \mathrm{Ph}(65 \%)$

14d: $\mathrm{R}=\left(\mathrm{CH}_{2}\right)_{2} \mathrm{OCH}_{3}(37 \%)$
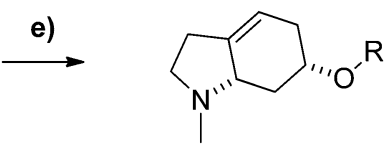

2a: $\mathrm{R}=\mathrm{CH}_{3}(84 \%)$

2b: $\mathrm{R}=\mathrm{CH}_{2} \mathrm{CH}_{3}(97 \%)$

2c: $\mathrm{R}=\mathrm{CH}_{2} \mathrm{Ph}(38 \%)$

2d: $\mathrm{R}=\left(\mathrm{CH}_{2}\right)_{2} \mathrm{OCH}_{3}(96 \%)$

${ }^{a}$ All compounds were prepared as racemic mixtures of pure diastereomers. (a) PIFA (1.2 equiv), $\mathrm{NaHCO}_{3}$ (4 equiv), $\mathrm{MeOH}$, $0^{\circ} \mathrm{C}, 1 \mathrm{~h}, 65 \%$. (b) $\mathrm{NaHCO}_{3}$ (5 equiv), $\mathrm{MeOH}, \mathrm{rt}, 15 \mathrm{~h}, 94 \%$. (c) $\mathrm{Zn}$ (Rieke, 5.1 equiv), $\mathrm{AcOH}$ (1.9 equiv), $\mathrm{MeOH}, \mathrm{rt}, 25$ min; $\mathrm{NaBH}_{4}(2.9$ equiv), $\mathrm{CeCl}_{3}$ (0.14 equiv), $\mathrm{MeOH},-30{ }^{\circ} \mathrm{C}, 2 \mathrm{~h}, 82 \%$ (2 steps). (d) $\mathrm{NaH}$ (2.5 equiv), DMF, $0{ }^{\circ} \mathrm{C}, 30 \mathrm{~min}$, then alkyl halide (2.5-4.4 equiv), rt, $12-15$ h, 14a $89 \%, 14 b 41 \%, 14 c 65 \%$, 14d $37 \%$. (e) LAH (3 equiv), THF, $70{ }^{\circ} \mathrm{C}, 3$ h, 2a $84 \%, 2 b$ 97\%, 2c $38 \%$, 2d 96\%. (f) (1) $\mathrm{NaH}$ (2.5 equiv), DMF, $0{ }^{\circ} \mathrm{C}, 30 \mathrm{~min}$, then MeI (4.0 equiv), rt, $15 \mathrm{~h}$. (2) TFA, $\mathrm{CH}_{2} \mathrm{Cl}_{2}, 0{ }^{\circ} \mathrm{C}, 1 \mathrm{~h}, 85 \%$. (g) LAH (3 equiv), THF, $70{ }^{\circ} \mathrm{C}, 3$ h, $87 \%$. (h) TFA, $\mathrm{CH}_{2} \mathrm{Cl}_{2}, 0{ }^{\circ} \mathrm{C}, 1 \mathrm{~h}, 89 \%$.

Scheme 3. Synthesis of Di-Unsaturated AB Fragment $3^{a}$<smiles>O=[R6]([O-])NCCC1(O)C=CC(=O)C=C1</smiles>

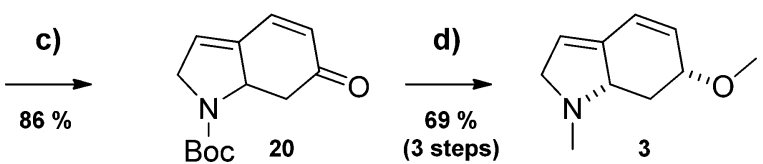

${ }^{a}$ The compound was prepared as a racemic mixture of a single diastereomer. (a) PIFA (1.2 equiv), $\mathrm{NaHCO}_{3}$ (4 equiv), $\mathrm{MeCN}, \mathrm{H}_{2} \mathrm{O}$, $0^{\circ} \mathrm{C}, 1 \mathrm{~h}, 69 \%$. (b) $\mathrm{NaHCO}_{3}$ (5 equiv), $\mathrm{MeOH}, \mathrm{rt}, 15 \mathrm{~h}, 92 \%$. (c) $\mathrm{POCl}_{3}$ (2.5 equiv), pyridine, rt, $15 \mathrm{~h}, 86 \%$. (d) $\mathrm{NaBH}_{4}$ (1.0 equiv), $\mathrm{CeCl}_{3}$ (0.1 equiv), $\mathrm{MeOH},-30{ }^{\circ} \mathrm{C}, 30 \mathrm{~min}, 90 \% ; \mathrm{NaH}$ (1.5 equiv), DMF, $0{ }^{\circ} \mathrm{C}, 30 \mathrm{~min}$, then MeI ( 5 equiv), rt, $15 \mathrm{~h}, 86 \%$; LAH ( 3 equiv), THF, $70{ }^{\circ} \mathrm{C}, 3 \mathrm{~h}, 89 \%$.

All 14 compounds were characterized in a $\left[{ }^{3} \mathrm{H}\right]$ epibatidine binding assay using membranes from HEK293 cells stably expressing the rat heteromeric nAChR subtypes $\alpha 4 \beta 2, \alpha 4 \beta 4$, and $\alpha 3 \beta 4 .{ }^{31}$ The functional properties of the analogues were characterized at a HEK293T cell line stably expressing the mouse $\alpha 4 \beta 2 \mathrm{nAChR}$ and at a HEK293 cell line stably expressing the rat $\alpha 3 \beta 4 \mathrm{nAChR}$ in the FLIPR Membrane Potential Blue (FMP) assay. Pharmacological evaluation of the natural product fragments $\mathbf{1} \mathbf{a}, \mathbf{2} \mathbf{a}$, and $\mathbf{3} \mathbf{a}$ revealed that the saturation level of the bicyclic core has a remarkable effect on the affinity (Table 1). The fully saturated fragment 1a

Table 1. Pharmacological Data of Fragments 1a, 2a, and $3 a^{a}$

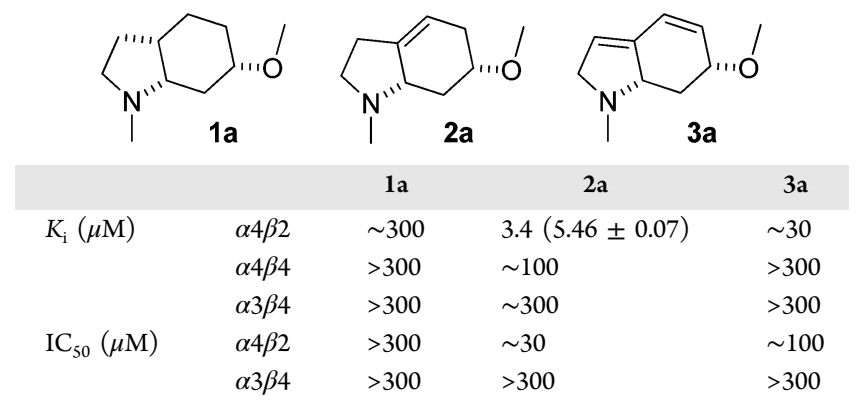

${ }^{a}$ The $K_{\mathrm{i}}$ values obtained for the compounds in the $\left[{ }^{3} \mathrm{H}\right]$ epibatidine binding assays are given in $\mu \mathrm{M}$ (with $\mathrm{p} K_{\mathrm{i}} \pm$ S.E.M. value in the bracket). The $\mathrm{IC}_{50}$ values obtained for the compounds at $\alpha 4 \beta 2$ and $\alpha 3 \beta 4$ in the FMP assay are given in $\mu \mathrm{M}$. The data are the means of 34 individual experiments.

mimicking the $\mathrm{AB}$ ring structure of $\mathrm{TH} \beta \mathrm{E}$ was completely devoid of affinity $(>300 \mu \mathrm{M})$ toward the nAChRs, whereas the affinity for the mono-unsaturated analogue $2 \mathrm{a}$ increased a factor of at least $100(3.4 \mu \mathrm{M})$ compared to its saturated derivative $\mathbf{1 a}$. Fragment 2a possesses the same saturation level as $\mathrm{DH} \beta \mathrm{E}$, and it was highly subtype selective against the $\alpha 4 \beta 2$ receptor. Indeed we were able to maintain the affinity of the small fragment $2 \mathrm{a}$ in the range of the parent natural product $\mathrm{DH} \beta \mathrm{E}$ $(0.82 \mu \mathrm{M})$ and with comparable subtype selectivity. The functional assay showed a lower antagonist potency $(30 \mu \mathrm{M})$ of the unsaturated analogue compared to $\mathrm{DH} \beta \mathrm{E}(1.2 \mu \mathrm{M})^{32}$ but still antagonize $\mathrm{nAChR}$ with similar efficacy. Interestingly, the binding affinity of the di-unsaturated analogue $3 a$, which mimics $\beta \mathrm{E}$ with respect to saturation level, proved to be intermediate of those of $\mathbf{1 a}$ and $\mathbf{2} \mathbf{a}$, thus further underlining the importance of the conformation of the $A B$ ring system. These results correlate well with a previous comparison of the parent natural products $\mathrm{TH} \beta \mathrm{E}, \mathrm{DH} \beta \mathrm{E}$, and $\beta \mathrm{E}$ (Chart $1 \mathrm{~b}$ ) revealing that the mono-unsaturated $\mathrm{A}$ ring has the highest affinity $(0.14$ $\mu \mathrm{M})$ followed by the di-unsaturated $(1.1 \mu \mathrm{M})$ and last the saturated A ring $(7.4 \mu \mathrm{M}))^{22}$ Thus, there was roughly a 10 -fold increase in the affinity for the mono-unsaturated natural product compared to the di-unsaturated, which is also the case in this study. However, we report a striking loss of affinity by moving from the di-unsaturated fragment $3 a$ to the saturated fragment 1a, indicating that some conformational changes are likely to occur in the simple fragments compared to the tetracyclic natural products.

We speculate that the different pharmacological profile of 1a and $\mathbf{2} \mathbf{a}$ is due to a conformational difference in the saturated versus the unsaturated ring system. A possible intramolecular hydrogen bond between the oxygen lone pair and the protonated nitrogen would lead to a favorable 6-membered ring and thereby placing the two pharmacophoric elements in a diaxial relationship rather than the necessary diequatorial conformation (Scheme 4). ${ }^{33}$

Because of the rigidity of the unsaturated fragments (2a and $3 a)$, this intramolecular interaction is not favorable, and thus, the pharmacophores are situated in the preferred diequatorial conformation. Presumably the tetracyclic framework in $\mathrm{TH} \beta \mathrm{E}$ 
Scheme 4. Possible Internal Hydrogen Bond in 1a Could Stabilize the Diaxial Conformation; the Diaxial Conformation Is Not Possible in the Unsaturated Analogues

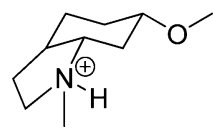

Diequatorial Conformation

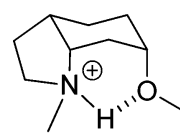

Diaxial

Conformation locks the $\mathrm{AB}$ ring systems in the diequatorial conformation, thereby maintaining affinity.

The effect of changing the $\mathrm{N}$ - and $\mathrm{O}$-substituents on the 1a and 2a scaffold is summarized in Chart 2. Unfortunately, all manipulation with these parts of the fragments was detrimental to the affinity with $K_{\mathrm{i}}$ values ranging from 100 to $>300 \mu \mathrm{M}$ (i.e., Supporting Information). Deleting the NMe group of 2a to provide $\mathbf{1 5}$ resulted in a complete loss of affinity. Similarly, the removal of the OMe group also leads to inactive fragments $(8$ and 16), and removing both the NMe and OMe group (9 and 17) also gave inactive ligands. The introduction of larger $\mathrm{O}$ substituents also gave inactive ligands presumably due to steric clash within the binding pocket exemplified by the complete loss of affinity when going from OMe to OEt ( $2 \mathbf{b}$ to $\mathbf{2 c}$ ). The attempt to dislodge the water molecule in the binding pocket with ligands $\mathbf{1 d}$ and $\mathbf{2 d}$ was also unsuccessful.

Chart 2. Synthesized N- and O-Functionalized Fragments; All Ligands Displayed Low Binding Affinities to the $\alpha 4 \beta 2$ Receptor $\left(K_{\mathrm{i}}\right.$ Values Ranging from $\sim 100$ to $>300 \mu \mathrm{M}$ )

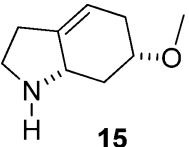

15<smiles>CN1CCC2=CC[C@H](O)C[C@@H]21</smiles>

$8 / 16$
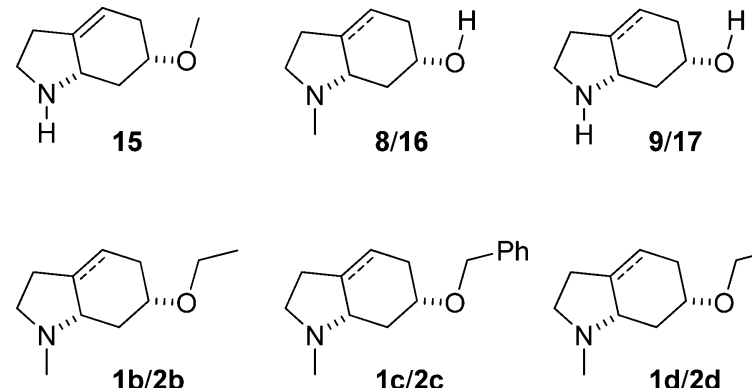

$1 b / 2 b$
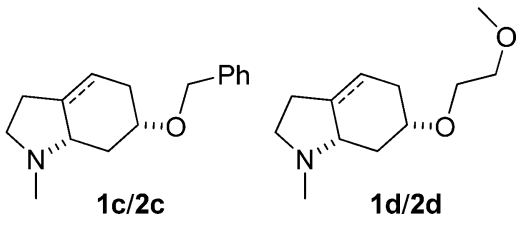

In conclusion, we have investigated the effect of excluding the $\mathrm{CD}$ rings in combination with adjusting the saturation levels of the $\mathrm{AB}$ rings in $\mathrm{DH} \beta \mathrm{E}$ on their pharmacological properties at $\mathrm{nAChRs}$. We found that the direct analogue of $\mathrm{DH} \beta \mathrm{E}$ maintained the activity at the $\alpha 4 \beta 2$ substype of the nAChRs, thereby substantiating the suggested binding mode of $\mathrm{DH} \beta \mathrm{E}$ with two key pharmacophoric elements, as found in the $\mathrm{X}$-ray structure in complex with the AChBP. However, even very small modifications to this structure leads to a drastic decline in the affinity for the nAChRs.

\section{ASSOCIATED CONTENT}

\section{S Supporting Information}

Full experimental details including copies of NMR spectra and pharmacological characterization of the compounds. This material is available free of charge via the Internet at http:// pubs.acs.org.

\section{AUTHOR INFORMATION}

\section{Corresponding Author}

*(J.L.K.) E-mail: jesper.kristensen@sund.ku.dk.

\section{Author Contributions}

T.H.J., A.A.J., and J.L.K. conceived the experiments. T.H.J., M.H.L., and E.G. synthesized the compounds. A.A.J. tested the compounds. T.H.J., A.A.J., and J.L.K. wrote the manuscript.

\section{Funding}

The Novo Nordisk Foundation and Jeppe Juhls Mindelegat are gratefully acknowledged for financial support.

\section{Notes}

The authors declare no competing financial interest.

\section{REFERENCES}

(1) Dwoskin, L. P.; Crooks, P. A. Competitive neuronal nicotinic receptor antagonists: A new direction for drug discovery. J. Pharmacol. Exp. Ther. 2001, 298, 395-402.

(2) Faundez-Parraquez, M.; Farias-Rabelo, N.; Gonzalez-Gutierrez, J. P.; Etcheverry-Berrios, A.; Alzate-Morales, J.; Adasme-Carreño, F.; Varas, R.; Bermudez, I.; Iturriaga-Vásquez, P. Neonicotinic analogues: Selective antagonists for $\alpha 4 \beta 2$ nicotinic acetylcholine receptors. Bioorg. Med. Chem. 2013, 21, 2687-2694.

(3) Duroure, L.; Jousseaume, T.; Araoz, R; Barre, E.; Retailleau, P.; Chabaud, L.; Molgo, J.; Guillou, C. 6,6-Spiroimine analogs of (-)-gymnodimine A: synthesis and biological evaluation on nicotinic acetylcholine receptors. Org. Biomol. Chem. 2011, 9, 8112-8118.

(4) Ambrus, J. I.; Halliday, J. I.; Kanizaj, N.; Absalom, N.; Harpsoe, K.; Balle, T.; Chebib, M.; McLeod, M. D. Covalent attachment of antagonists to the $\alpha 7$ nicotinic acetylcholine receptor: synthesis and reactivity of substituted maleimides. Chem. Commun. 2012, 48, 66996701.

(5) Barker, D.; Lin, D. H.; Carland, J. E.; Chu, C. P.; Chebib, M.; Brimble, M. A.; Savage, G. P.; McLeod, M. D. Methyllycaconitine analogues have mixed antagonist effects at nicotinic acetylcholine receptors. Bioorg. Med. Chem. 2005, 13, 4565-4575.

(6) Lippiello, P. M. Nicotinic cholinergic antagonists: a novel approach for the treatment of autism. Med. Hypotheses 2006, 66, 985990.

(7) Shytle, R. D.; Silver, A. A.; Lukas, R. J.; Newman, M. B.; Sheehan, D. V.; Sanberg, P. R. Nicotinic acetylcholine receptors as targets for antidepressants. Mol. Psychiatry 2002, 7, 525-535.

(8) Shyttle, R. D.; Penny, E.; Silver, A. A.; Goldman, J.; Sanberg, P. R. Mecamylamine (Inversine): an old antihypertensive with new research directions. J. Hum. Hypertens. 2002, 16, 453-457.

(9) Phillip, N. S.; Carpenter, L. L.; Tyrka, A. R.; Price, L. H. The nicotinic acetylcholine receptor as a target for antidepressant drug development. Sci. World J. 2012, 104105, 1-7.

(10) Lippiello, P. M.; Beaver, J. S.; Gatto, G. J.; James, J. W.; Jordan, K. G.; Traina, V. M.; Xie, J.; Bencherif, M. TC-5214 (S-(+)-Mecamylamine): A neuronal nicotinic receptor modulator with antidepressant activity. CNS Neurosci. Ther. 2008, 14, 266-277.

(11) Crooks, P. A.; Bardo, M. T.; Dwoskin, L. P. Nicotinic receptor antagonists as treatments for nicotine abuse. Adv. Pharmacol. 2014, 69, $513-551$.

(12) Quattrocki, E.; Baird, A.; Yurgelun-Todd, D. Biological aspects of the link between smoking and depression. Harvard Rev. Psychiatry 2000, 8, 99-110.

(13) Andreasen, J. T.; Olsen, G. M.; Wiborg, O.; Redrobe, J. P. Antidepressant-like effects of nicotinic acetylcholine receptor antagonists, but not agonists, in the mouse forced swim and mouse tail suspension tests. J. Psychopharm. 2009, 23, 797-804.

(14) Jensen, A. A.; Frolund, B.; Liljefors, T.; Krogsgaard-Larsen, P. Neuronal nicotinic acetylcholine receptors: Structural revelations, target identifications, and therapeutic inspirations. J. Med. Chem. 2005, $48,4705-4745$

(15) Setti-Perdigao, P.; Serrano, M. R. A.; Flausino, O. A., Jr.; Bolzani, V. S.; Guimaraes, M. Z. P.; Castro, N. G. Erythrina mulungu 
alkaloids are potent inhibitors of neuronal nicotinic receptor currents in mammalian cells. PLoS One 2013, 8, e82726.

(16) Paul, W. D.; Zavala, D. C. Management of spasm in poliomyelitis; use of various drugs, especially dihydrobetaerythroidine, in acute cases. Med. Times 1951, 79, 463-467.

(17) Binger, G. G.; Devnich, G. Treatment of two cases of tetanus with D-tubocurarine chloride in peanut oil with myricin. Anesthesiology 1950, 11, 199-205.

(18) Popik, P.; Kozela, E.; Krawczyk, M. Nicotine and nicotinic receptor antagonists potentiate the antidepressant-like effects of imipramine and citalopram. Br. J. Pharmacol. 2003, 139, 1196-1202.

(19) Shahsavar, A.; Kastrup, J. S.; Nielsen, E. Ø.; Kristensen, J. L.; Gajhede, M.; Balle, T. Crystal structure of Lymnaea stagnalis AChBP complexed with the potent $\mathrm{nAChR}$ antagonist $\mathrm{DH} \beta \mathrm{E}$ suggests a unique mode of antagonism. PLoS One 2012, 7, e40757.

(20) Iturriaga-Vásquez, P.; Carbone, A.; García-Beltrán, O.; Livingstone, P. D.; Biggin, P. C.; Cassels, B. K.; Wonnacott, S.; Zapata-Torres, G.; Bermudez, I. Molecular determinants for competitive inhibition of $\alpha 4 \beta 2$ nicotinic acetylcholine receptors. Mol. Pharmacol. 2010, 78, 366-375.

(21) Crestey, F.; Jensen, A. A.; Borch, M.; Andreasen, J. T.; Andersen, J.; Balle, T.; Kristensen, J. L. Design, synthesis, and biological evaluation of erythrina alkaloid analogues as neuronal nicotinic acetylcholine receptor antagonists. J. Med. Chem. 2013, 56, 9673-9682.

(22) Wildeboer, K. M. Structure Activity Relationship of Nicotine Analogs and Erythrina Alkaloids on the $\alpha 4 \beta 2$ Nicotinic Acetylcholine Receptor. Ph.D. thesis, University of Florida, 2005.

(23) Decker, M. W.; Anderson, D. J.; Brioni, J. D.; Donnelly-Roberts, D. L.; Kang, C. H.; O’Neill, A. B.; Piattoni-Kaplan, M.; Swanson, S.; Sullivan, J. P. Erysodine, a competitive antagonist at neuronal nicotinic acetylcholine receptors. Eur. J. Pharmacol. 1995, 280, 79-89.

(24) Bonjoch, J.; Catena, J.; Valls, N. Total synthesis of ( \pm )-deethylibophyllidine: Studies of a fischer indolization route and a successful approach via a pummerer rearrangement/thionium ionmediated indole cyclization. J. Org. Chem. 1996, 61, 7106-7115.

(25) Constantino, M. G.; de Oliveira Matias, L. G.; da Silva, G. V. J.; Barbieri, E. Stereoselective sodium borohydride reductions of cyclopentanones: influence of ceric chloride on the stereochemistry of reaction. Quim. Nova 1998, 21, 719-721.

(26) Wipf, P.; Kim, Y.; Goldstein, D. M. Asymmetric total synthesis of the stemona alkaloid (-)-stenine. J. Am. Chem. Soc. 1995, 117, $11106-11112$.

(27) Gu, Q.; You, S. Desymmetrization of cyclohexadienones viacinchonine derived thiourea-catalyzed enantioselective aza-Michael reaction and total synthesis of (-)-mesembrine. Chem. Sci. 2011, 2, $1519-1522$.

(28) Kita, Y.; Tohma, H.; Kikuchi, K.; Inagaki, M.; Yakura, T. Hypervalent iodine oxidation of $N$-acyltyramines: synthesis of quinol ethers, spirohexadienones, and hexahydroindol-6-ones. J. Org. Chem. 1991, 56, 435-438.

(29) Nicolaou, K. C.; Totokotsopoulos, S.; Giguére, D.; Sun, Y.; Sarlah, D. Total synthesis of epicoccin G. J. Am. Chem. Soc. 2011, 133, $8150-8153$.

(30) Guan, Y.; Zhang, H.; Pan, C.; Wang, J.; Huang, R.; Li, Q. Flexible synthesis of montanine-like alkaloids: revisiting the structure of montabuphine. Org. Biomol. Chem. 2012, 10, 3812-3814.

(31) Jensen, A. A.; Mikkelsen, I.; Frølund, B.; Brauner-Osborne, H.; Falch, E.; Krogsgaard-Larsen, P. Carbamoylcholine homologs: Novel and potent agonists at neuronal nicotinic acetylcholine receptors. Mol. Pharmacol. 2003, 64, 865.

(32) Pharmacological data for $\mathrm{DH} \beta \mathrm{E}$ was obtained from the same assay.

(33) de Oliveira, P. R.; Ribeiro, D. S.; Rittner, R. Influence of intramolecular hydrogen bonding on the conformational equilibrium of cis-3-N,N-dimethylaminocyclohexanol compared with trans-3-N,Ndimethylaminocyclohexanol and cis- and trans-3-N,N-dimethylamino1-methoxycyclohexane. J. Phys. Org. Chem. 2005, 18, 513-521. 